\title{
A Novel Adaptive Mobile E-Learning Model
}

\author{
Ahmed Abou Elfetouh S. \\ Head of Information Systems Dept. \\ Faculty of Computer Sciences and Information \\ Systems
}

\begin{abstract}
Adaptive E-Learning has become an important topic. It gives the student a central role in his/her own learning process. It allows students to try things out, participate in courses, tests and simulations like never before, and get more out of learning than before. On the other hand, mobile E-Learning has many advantages that contribute in enhancing and facilitating the learning process. In this paper, an adaptive mobile E-Learning (AME-Learning) model for system numbers, logic design, simplification of Boolean functions and related fields is presented. Such model presents suitable courses for each student in a dynamic and adaptive manner using existing database and workflow technologies. The presented model generates suitable units for each student in a dynamic form. Even the choice of effective E-Learning tools is seemingly endless. The main objective of this research work is to provide an AME-Learning model on based learners' personality using explicit and implicit feedback. To recognize the learner's style and profile, the dimensions given by both Felder-Silverman learning style model and our previous work [24-29] are developed. This is important to decide each individual learning style in order to accommodate different abilities for each student and develop his/her vital skills. Thus, the proposed model becomes more powerful, user friendly and easy to use and interpret. Finally, it suggests a learning strategy and appropriate electronic media that match the learner's preference. The proposed environment is designed by using Visual Basic for modeling and Microsoft word for creating materials.
\end{abstract}

\section{Keywords}

Adaptive learning, mobile learning, Learning styles, Teaching strategies.

\section{INTRODUCTION}

The sustained growth in E-Learning helps to provide a powerful mechanism to enhance learning depth, and involve learners with the material [1-18]. In traditional lecture methods, the professor talks and students listening in a passive way, unlike in active learning students doing, observing and communicating, so they become more interactive by finding better ways to engaging them in learning process. Blended learning is defined as learning that combines instruction lead learning with online learning activities leading to reduced classroom contact hours. It has the potential to increase student learning while lowering attend rates compared to equivalent fully online courses [19]. Blended learning is the

\author{
Hazem M. El-Bakry \\ Dept. of Information Systems \\ Faculty of Computer Sciences and Information \\ Systems
}

learning paradigm that attempts to optimize both traditional learning and distance learning advantages, potentials, and benefits while eliminating both learning paradigms shortages and challenges. Nowadays blended learning is commonly referred to as E-Learning. When compared to traditional learning paradigm, blended learning is found to be consistent with the values of traditional learning paradigm adopted in almost all higher education learning institutions for decades, and has the proven potential to enhance both the effectiveness and efficiency of meaningful learning experiences [1-20].

This paper introduces an environment where learners participate in learning process effectively, and teachers have an instructive role, instead of transmitting information in materials to learners directly. Adaptive E-Learning is always focusing on the learner, although it sometimes involves tutors. In the presented model, some basic principles are considered for active construction learning model including the following [20-24]:

1-Learners participate in learning process effectively

2-teachers have an instructive role, instead of transmitting information in materials to learners directly.

3- Assessment procedures should be embedded in the learning process

The proposed model can be used as an adaptive E-Learning tool for active learning not for numerical systems course only but also for all educational courses as image processing, logic design, and other fields. Nowadays, the concept of number systems course has important role in a wide range of applications as data representation, internal operations of the computer, performing calculations, and comparing amounts. Before writing this paper, multiple tests have been done in the classroom for the framework as a model of adaptive active learning tool. The preliminary results were clear in improving the learners understanding, performance, and increase their motivation. It is proved that the proposed model is easy to use and attractive for learners. With the blooming of technologies, the popularity of electronic learning programs enforces us to think about what advanced technologies can enhance learning depth, involve learners with the material, and increase material retention. Different humans have different learning ways. Some can assimilate knowledge in a better way when received auditory, visually or through another sense [25]. Traditional teaching styles tend to use one of these 
presentations more than others [26]. It is extremely difficult for a teacher to apply all multiple teaching strategies in a classroom. Nowadays, adaptive learning provide new ways to break of the traditional educational models one size fits all approach and make it possible to customize down to the individual [27]. An adaptive system adapts itself or another system in order to deal with different situations and fit to various circumstances [28]. Adaptive learning systems endeavor to transform the learner from passive receptor of information to collaborator in the educational process [29]. Those learning systems' primary application is in education, but another popular application is business training.

Nowadays, Mobile Learning has become an important issue. This is because it has the many valuable befits. First, it allows students learn at any time and any place. Second, students can save their time. Third, fast learning can by achieved through mobile communications. Fourth, using mobile phone is more flexible rather than PC. Finally, the concentration of students is more increasingly when using mobile learning. One of the most important differences between content on mobile devices and content on PC's is that the input for mobile devices has largely moved to direct input with the finger on the screen. Whereas a PC uses a mouse to interact with the graphical user interface, the mobile device uses the finger. The practical reality here is that touching things makes us feel differently about those things. This is the core idea behind interface differences in mobile. Associative pictures are painted in our minds and the things we touch and handle directly. Some of the interactions that we know from PC's, like clicking and double clicking seem to have parallels in the world of mobile devices. We click on an icon or button on a PC, whereas we tap it on the phone or tablet. The obvious difference is that our eye and finger are focused on the same place with the mobile device and hence we can physically feel the mobile device when we touch it. What we may not realize is that mousing on a PC actually has many variations of the click. Clicks for example are generally divided into the down and the up phase. This is why we can click down on a button, then roll mouse off that button, and then clicks up - thereby canceling an unintended mouse interaction. We don't have that luxury with a direct finger interaction. That said, there are many ways that the finger inputs can be used to create interesting and logical user inputs. Now for the most part we'll rely on content creation tools to assist we in creating the interactions of clickable objects etc, but it is important to know a little about the differences in order to make content behave logically on the mobile device [30].

Our proposed model can be used as an AME-Learning tool for active learning not for logic design course only but also for all educational courses as image processing, computational models, principles of programming languages, compiler design, and other related courses. Important topics are covered in our proposed environment. Such topics are integrated into a single environment using visual basic. So it appears to be portable, and machine independent, which makes it a useful tool for interactive and collaborative learning environment. The environment integrates several different materials to support the learners' preferred style. It includes a movie-like welcome component, an animated hyper-text introduction for the basic concepts, self assessment system, a logic gate simulator, a set of visual examples for learners' motivation.

Without knowing anything about the user, a system would perform in an exactly the same way for all users [31]. To individualize, personalize or customize actions a user profile is needed. The user information is stored and managed in form of user profile. Thus a user profile represents the system's beliefs about the user. The behavior of an adaptive system differs according to data in this profile. Based on this data, the person's individual learning style is identified by using the learning styles dimensions. Then the system is rendering suitable course content in a dynamic form for each student, and adapting instructions toward that learner's strengths and preferences. Each course is divided into units. After a particular unit in a course is completed, a quiz is provided. The displayed course material to the user will be personalized with respect to his character. This is to enable him learn the subject in the most effective way and in the shortest possible time.

The proposed model covers the concept of digital design course. In fact most of our modern life technologies deal with the concept of digital design [32]. Digital logic has important use in all of today's digital computers and devices. It has such a prominent role in every day life in recent digital age [33]. Digital systems are used in communication, traffic control, medical treatment, space guidance, weather monitoring, the Internet and other huge enterprises [34]. Also the digital electronic circuits are the engines of digital cameras, computers, cell phones, MPEG players, GPS displays, handheld devices and other products using information in digital formats. Our proposed model can be used as an AMELearning model not only for logic design course but also for all educational courses as image processing, computational models, principles of programming languages, compiler design, and other related courses.

Important topics are covered in our proposed environment. Such topics are integrated into a single environment using visual basic. So it appears to be portable, and machine independent, which makes it a useful tool for interactive and collaborative learning environment. The environment integrates several different materials to support the learners' preferred style. It includes a starting form used to gather information about user, a movie-like welcome component, an animated hyper-text introduction for the basic concepts, self assessment system, a logical simulator, and a set of visual examples for learners' motivation. The proposed model is designed by integrating visual basic, flash, Microsoft access, and other effective tools.

Before writing this paper, several classroom experiments were carried out for the framework as a model of adaptive learning based on user learning styles, teaching strategies and implementation of electronic media. The preliminary results were clear in improving the learners understanding, performance, and increase their motivation. It is proved that the proposed model facilitates and personalizes the learning process, which provides easy and attractive use for learners.

\section{RELATED WORK}

There are different tools used to categorize each person according to their learning styles: Kolb questionnaire, honey 
and Mumford questionnaire [35-36], GRSLSS questionnaire [36], Myers-Briggs type indicator [37], and finally FelderSilverman [38].

In [37], the authors suggested new teaching strategies on ELearning context matching with learner's personality using the Myers-Briggs Type Indicator tools. There are several studies focus on the effectiveness of multimedia and learning styles in the educational systems [39-40]. But few give an idea of which combinations of learning styles and electronic media are more effective than others.

Another study in [41] described the development of learning styles integration taxonomy, teaching strategies and the proper implementation of electronic media to personalize the learning process. The design of this personalized teaching environment based on an adaptive taxonomy using Felder and Silverman's learning styles. The adaptation in Tangow [42] lies in presenting a different sequence of alternative contents of the concepts. Concepts can be represented by example and exposition. The system uses only the Sensing-intuitive dimension from the Felder-Silverman learning style model. The PHP programming course [43] provided different representations for each learner, and used different types of resources such as theory, colors, text, slideshows, audio, etc. One disadvantage of PHP programming course was that electronic media is limited to graphics, audio, video, and hypertext and that doesn't integrate teaching strategies. The course presented in [44] achieved adaptation by providing different representations for each learner. Also different types of resources were used. In this sense, our proposed model is significantly different from the previous efforts done in this field.

Due to the importance of digital design and the growth within internet based technologies, the authors in [45] realized a Java programmed testing system. Such system which is a component in an Internet based Digital Logic Design Virtual Laboratory realized to the stage of tasks delivery. A set of virtual instruments are at the disposal of the laboratory. Each instrument is designed to be used by the students to present the decisions of tasks of distinct type. The test consists of a number of tasks. Every teacher defines a desired number of tasks which are stored in a database. Another application presented in [46] based on Adobe Flash and SCORM within a MOODLE learning environment. It provides individualized assignments for students learning digital systems. The assignments are evaluated automatically and the result is reported to the MOODLE platform. Since the tasks are solved by the students remotely and unattended, students get their personalized assignment by selecting one from the pool of available assignments based on the student's unique learner id. While the authors in [32] presented an overview of an ELearning system and discussed some web-based tools for teaching the basics of digital logic in such a system. Also the authors in [47] presented a web-based system for teaching logic design concepts and practices for computer science and engineering students. Such system was implemented by using LabVIEW. The experiments which included digital logic gates, combinational logic circuits, seven segment display, sequential logic and counters were easily constructed and performed, both in traditional and online setups. Vladimir Mateev [48] provided a Web-based virtual instrument for testing students' knowledge to construct truth tables of analytically-defined Boolean functions. It was a component of the testing subsystem of the Internet based Digital Logic Design Virtual Laboratory (DLDVL) that can be used from authorized users only. The instrument was realized as a Java applet.

\section{THE PROPOSED MODEL}

The presented model provides a basic treatment of digital circuits and the fundamental concepts in their design. It is suitable for use as an introductory course in an electrical engineering, computer engineering, or computer science curriculum. Learners usually found logical design materials boring and complex. That's because the learners find materials difficult to visualize or even interact with. Especially when material includes coverage of low level electronics, electronic circuits, Boolean function, combinational logic and Karnaugh map then learners can lose interest or perceive higher levels of complexity.

The choices of effective E-Learning tools are seemingly endless, according to availability of multiple tools. Visual basic (version 6) is integrated with flash and other tools as an example of simple adaptive learning tools that improve the learner's performance in classes.

The first component in the implemented framework is the starting registration form. It contains simple questions to be filled by current user in addition to his name as shown in Fig.1. When the user presses result, Fig. 2 appears.

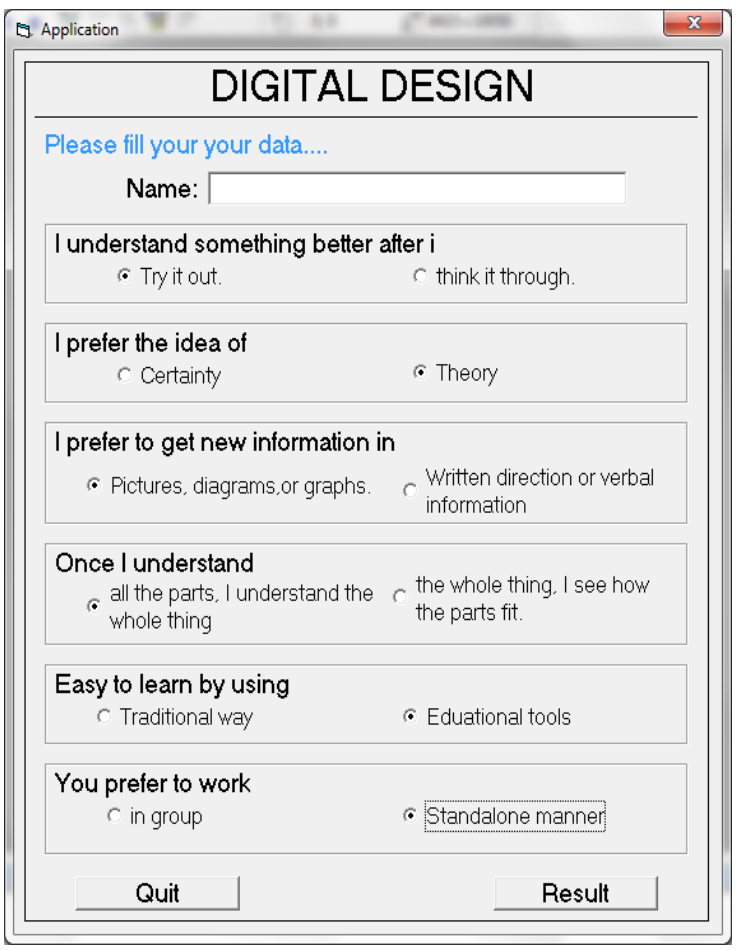

Fig. 1. Starting registration form 


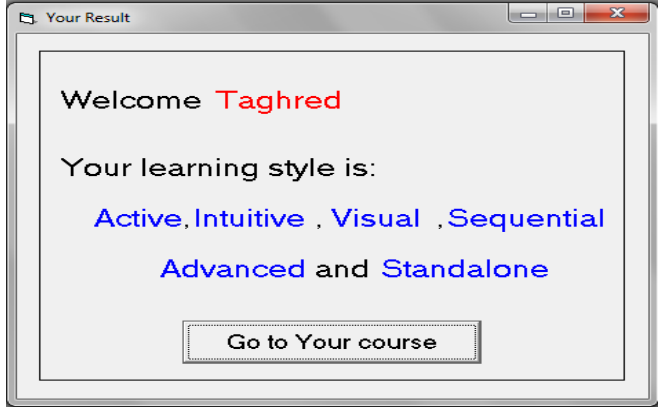

Fig. 2. The resulted learning style.

The explicit feedback is presented at the starting of the proposed framework. This is in order to prevent interrupting the normal process of learning. While simple questions increase the interest for complete filling the questionnaire.

The questionnaire answers are sent to the system. The system gathers information about the learner and environment in a direct manner. Then all user-related data stored in the users' profiles, including personal information, preferences, and interaction with system. These properties are stored after assigning them values that may be final or change over time. Each learner has his own user profile which enables the system to deliver customized instruction, on the basis of the student's learning style. Learning style is defined as the characteristics, strengths and preferences in the way people receive and process information [38]. It refers to the fact that every person has different level of motivation, attitudes, and responses. Several tools are used to determine learners' learning styles. The dimensions of learners' learning styles given by Felder and Silverman's model are listed in Table 1.

Table 1. Learning Styles Dimensions given by FelderSilverman

\begin{tabular}{|c|c|c|}
\hline $\begin{array}{c}\text { Learning Style } \\
\text { Dimension }\end{array}$ & Type & Description \\
\hline \multirow[t]{2}{*}{$\begin{array}{l}\text { Processing } \\
\text { (LSD1) }\end{array}$} & $\begin{array}{l}\text { Active } \\
\text { (A) }\end{array}$ & Learning by doing style. \\
\hline & $\begin{array}{l}\text { Reflective } \\
\text { (Re) }\end{array}$ & $\begin{array}{l}\text { Learning by thinking } \\
\text { about information. }\end{array}$ \\
\hline \multirow[t]{2}{*}{$\begin{array}{l}\text { Perception } \\
\text { (LSD2) }\end{array}$} & $\begin{array}{l}\text { Sensitive } \\
\text { (S) }\end{array}$ & $\begin{array}{c}\text { Rather deal with facts, raw } \\
\text { data and experiments, } \\
\text { they're patient with } \\
\text { details. }\end{array}$ \\
\hline & $\begin{array}{l}\text { Intuitive } \\
\text { (I) }\end{array}$ & $\begin{array}{l}\text { Rather deal with } \\
\text { principles and theories, } \\
\text { are easily bored when } \\
\text { presented with details. }\end{array}$ \\
\hline \multirow[t]{2}{*}{$\begin{array}{l}\text { Entry Channel } \\
\text { (LSD3) }\end{array}$} & $\begin{array}{l}\text { Visual } \\
\text { (Vi) }\end{array}$ & $\begin{array}{l}\text { Easy to remember what } \\
\text { they see: images, } \\
\text { diagrams, time tables, etc. }\end{array}$ \\
\hline & $\begin{array}{l}\text { Verbal } \\
(\text { Ve) }\end{array}$ & $\begin{array}{l}\text { Remember what they've } \\
\text { heard, read or said. }\end{array}$ \\
\hline \multirow[t]{2}{*}{$\begin{array}{l}\text { Understanding } \\
\text { (LSD4) }\end{array}$} & $\begin{array}{l}\text { Sequential } \\
\text { (Seq) }\end{array}$ & $\begin{array}{c}\text { Follow a lineal reasoning } \\
\text { process when solving } \\
\text { problems and }\end{array}$ \\
\hline & $\begin{array}{c}\text { Global } \\
\text { (G) }\end{array}$ & $\begin{array}{l}\text { Take big intuitive leaps } \\
\text { with the information. }\end{array}$ \\
\hline
\end{tabular}

This model rates the student's learning style in a scale of four dimensions. Our model classifies learners into 12 axes: active vs. reflective, sensing vs. intuitive, visual vs. verbal, sequential vs. global, traditional vs. advanced, work in group vs. standalone, strong vs. week, helpful vs. not comfortable, ready to understand vs. not ready to understand, Poor vs. Rich, Receive encouragement vs. do not receive encouragement and Participate in actives vs. do not participate in activates. Table 2 shows our new learning styles dimensions. The active learners gain information through a learning by doing style, discussing or explaining it to others, while reflective learners gain information by thinking about it quietly first. Sensing learners tend to learn facts through their senses, while intuitive learners prefer discovering possibilities and relationships. Visual learners prefer images, diagrams, and graphics, while verbal learners remember what they've heard, read or said. Sequential learners gain understanding from logical continuous steps, while global learners take big intuitive leaps with the information. Traditional learners could assimilate information better using the traditional learning way without using illustrative educational tools, while advanced are keen to try things out. They tend to be impatient with long discussions and are practical and down to earth. Work in group learners tend to like group work and become more effective and motivated, while Standalone learners prefer working alone or in a small group contains only few persons so they could understand better.

There are 12 learning style dimensions $\mathrm{LSD}=\{\mathrm{LSD} 1$, LSD2, LSD3, LSD4, LSD5, LSD6, LSD7, LSD8, LSD9, LSD10, LSD11, LSD12 \}, Each dimension is a combination of six values, see TABLE I, LSD $=\{(\mathrm{A} / \mathrm{Re}),(\mathrm{S} / \mathrm{I}),(\mathrm{Vi} / \mathrm{Ve})$, (Seq/G), (W/St), (T/Ad), (Sg/We), (He/Nc), (Rs/Nu), $(\mathrm{Ps} / \mathrm{Rc})\}$. Then, there are $4096\left(2^{12}\right)$ learning styles combinations.

This does not mean that a person possesses only six styles, but that the six styles show a greater presence than their counterparts. For example everybody is active sometimes and reflective sometimes. The preference for one category or the other may be strong, moderate, or weak.

The applied modifications on learner's styles dimensions help learner to develop vital skills. Additional dimensions used to reduce the probabilities of error in determining the learner's learning styles. The process of selecting learner's style became more precise and specific. Thus, it could be used by college instructors and students in engineering and the sciences, although it could be applied in a broad range of disciplines.

The teaching strategies designed to encourage learners to observe, analyze, express an opinion, look for a solution and facilitate a deeper understanding of the information. The process of selecting suitable teaching strategy based on the resulted learning style. 
Table 2. The developed Learning Styles Dimensions

\begin{tabular}{|c|c|c|}
\hline $\begin{array}{c}\text { Learning } \\
\text { Style } \\
\text { Dimension }\end{array}$ & Type & Description \\
\hline \multirow[t]{2}{*}{$\begin{array}{l}\text { Realistic } \\
\text { (LSD5) }\end{array}$} & $\begin{array}{l}\text { Traditional } \\
(\mathbf{T}) \\
\end{array}$ & $\begin{array}{c}\text { Not prefer } \\
\text { educational tools }\end{array}$ \\
\hline & $\begin{array}{l}\text { Advanced } \\
\text { (Ad) }\end{array}$ & $\begin{array}{l}\text { Easy to learn by } \\
\text { using educational } \\
\text { tools }\end{array}$ \\
\hline \multirow[t]{2}{*}{$\begin{array}{l}\text { Behavior } \\
\text { (LSD6) }\end{array}$} & $\begin{array}{l}\text { Work in group } \\
\text { (W) }\end{array}$ & $\begin{array}{c}\text { Prefer working in } \\
\text { groups }\end{array}$ \\
\hline & $\begin{array}{c}\text { Standalone } \\
(\mathbf{S t})\end{array}$ & Prefer working alone \\
\hline \multirow[t]{2}{*}{$\begin{array}{l}\text { Healthcare } \\
\text { (LSD7 }\end{array}$} & $\begin{array}{l}\text { Strong } \\
\text { (Sg) }\end{array}$ & $\begin{array}{l}\text { Has the ability to be } \\
\text { active and cooperate }\end{array}$ \\
\hline & $\begin{array}{l}\text { Weak } \\
(\text { We) }\end{array}$ & $\begin{array}{l}\text { Not ready to learn } \\
\text { because of health } \\
\text { problems }\end{array}$ \\
\hline \multirow[t]{2}{*}{$\begin{array}{c}\text { Social } \\
\text { Environment } \\
\text { (LSD8) }\end{array}$} & $\begin{array}{l}\text { Helpful } \\
\text { (He) }\end{array}$ & $\begin{array}{l}\text { Social environment } \\
\text { such as family and } \\
\text { friends support him } \\
\text { to learn and } \\
\text { understand }\end{array}$ \\
\hline & $\begin{array}{l}\text { Not comfortable } \\
\text { (Nc) }\end{array}$ & $\begin{array}{l}\text { Not helpful (ex. } \\
\text { Generate noise, } \\
\text { speaking with loud } \\
\text { voices) }\end{array}$ \\
\hline $\begin{array}{c}\text { psychological } \\
\text { state } \\
\text { (LSD9) }\end{array}$ & $\begin{array}{l}\text { Ready to understand } \\
\text { (Rs) }\end{array}$ & $\begin{array}{l}\text { Ready to learn and } \\
\text { understand }\end{array}$ \\
\hline \multirow[t]{2}{*}{$\begin{array}{c}\text { Economical } \\
\text { State } \\
\text { (LSD10) }\end{array}$} & $\begin{array}{l}\text { Poor students are } \\
\text { serious } \\
\text { (Ps) }\end{array}$ & $\begin{array}{l}\text { Poor students do } \\
\text { their best to success }\end{array}$ \\
\hline & $\begin{array}{l}\text { Rich students do not } \\
\text { care } \\
\text { (Rc) }\end{array}$ & $\begin{array}{l}\text { Rich students do not } \\
\text { care because they } \\
\text { can learn in private } \\
\text { schools and } \\
\text { universities }\end{array}$ \\
\hline \multirow[t]{2}{*}{$\begin{array}{l}\text { Emotional } \\
\text { State } \\
\text { (LSD11) }\end{array}$} & $\begin{array}{c}\text { Receive } \\
\text { Encouragement } \\
\text { (En) }\end{array}$ & $\begin{array}{c}\text { Students who } \\
\text { receive } \\
\text { encouragement from } \\
\text { (ex: wife, boy/girl } \\
\text { friend, or mother) } \\
\text { have the ability to } \\
\text { learn } \\
\end{array}$ \\
\hline & $\begin{array}{c}\text { Do not receive } \\
\text { Encouragement } \\
(\mathbf{N e})\end{array}$ & $\begin{array}{c}\text { Students who } \\
\text { receive } \\
\text { encouragement from } \\
\text { have less ability to } \\
\text { learn } \\
\end{array}$ \\
\hline \multirow[t]{2}{*}{$\begin{array}{l}\text { Practicing } \\
\text { Sports or Arts } \\
\text { (LSD12) }\end{array}$} & $\begin{array}{l}\text { Participate in } \\
\text { activities } \\
\text { (Pa) }\end{array}$ & $\begin{array}{c}\text { Participating } \\
\text { students in different } \\
\text { actives have more } \\
\text { ability to understand }\end{array}$ \\
\hline & $\begin{array}{c}\text { Do not participate in } \\
\text { activities } \\
\text { (Na) }\end{array}$ & $\begin{array}{l}\text { Non participating } \\
\text { students have less } \\
\text { ability to understand }\end{array}$ \\
\hline
\end{tabular}

The framework suggests four strategy paths as in Fig. 3. LSC can be associated with a teaching strategy (TSi): TS = $\{\mathrm{TS} 1, \mathrm{TS} 2, \mathrm{TS} 3, \mathrm{TS} 4\}$. Teaching strategies hold a one-tomany relationship with the learning styles. There can be one or many teaching strategies that accommodate one learning style. Teaching strategies are given to learners to facilitate a deeper understanding of the information. The emphasis relies on the design, programming, elaboration and accomplishment of the learning content.
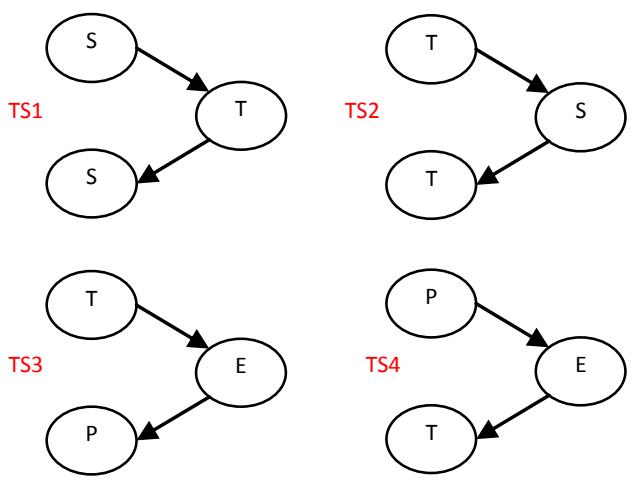

$\mathrm{S}$ SSimulator T:Theory E:Examples P:Practical exercise

Fig. 3. Learning strategies

The strategies make use of all resources, elements and components which have been integrated into a single environment. The first teaching strategy TS1 tends to use the Simulator-Theory-Simulator approach. The system starts by presenting the Simulator as an Application. The learners attempt to analyze and solve the problem without the benefit of the upcoming course's theory. Therefore, the teacher presents the chapter's theory or ideas, and the system presents additional applications to make the learning process so easy. The second teaching strategy TS2 uses the approach TheorySimulator-Theory. System starts by presenting the chapter's theory before simulator related. The learners attempt to analyze and solve the problem using the course's knowledge. They can reuse the theory to facilitate the learning process. In the third one, the system starts by presenting the chapter's theory or idea before examples related. Afterwards additional practical exercise and problem solving will be presented. The last strategy TS4 uses the opposite teaching of TS3.

It is not an easy task to teach the computer systems internal operation, learners usually found computer architecture materials boring and complex. The main reason of that is that learners find materials difficult to visualize or interact with. Especially when material includes coverage of low level electronics, Boolean logic and data representation then learners can lose interest or perceive higher levels of complexity. So, this paper supporting active E-Learning in data representation specially numbering systems, and provide a converter to convert automatically between these systems. It also provides educational course and testing system to generate exercises automatically. The choices of effective ELearning tools are seemingly endless, according to availability of multiple tools. We use visual basic 6 as an example of simple active learning tools that improves the learner's performance in classes. The implemented framework contains of three parts as shown in Fig. 4. 


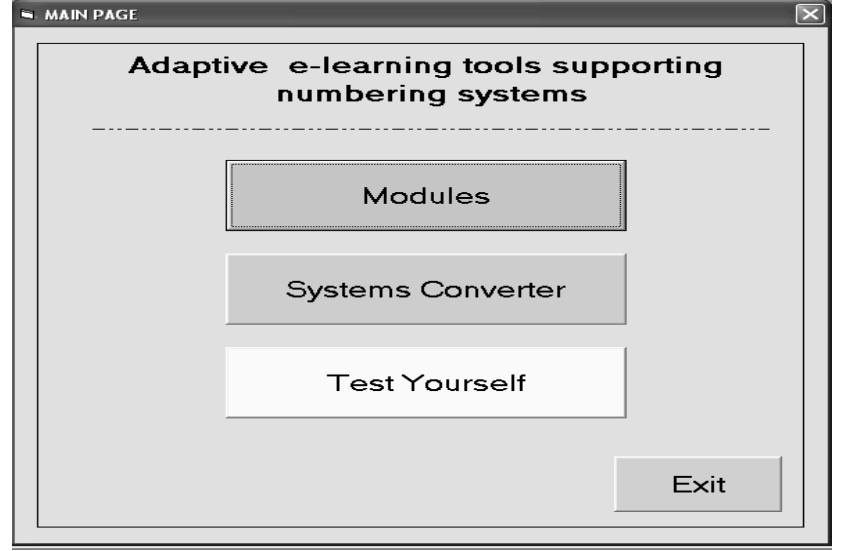

Fig. 4. Interface components in the framework

The framework generates the module course according to the understanding level of students. Here, teacher has an administration role in education process, but they also must construct the standard course material and other courses included in framework. We split the course material into 3 partitions which implemented as text file as shown in Fig. 5, and Fig. 6:

1. Standard course: it represents main units ordered in an ordinary way that learners can be master successfully.

2. Review course: should be studied when a learner makes wrong answers in the examination.

3. Special course: course material should be studied when learner makes popular mistakes in the examination.

The converter is the second part of the framework, it convert automatically between any two numerical systems, to assist learners enjoys, learning and trying what was studied in educational courses as shown in Fig. 7. Decimal, binary, octal, and hexadecimal are 4 numbers systems so we have 4 systems to convert from, and 4 systems to convert to them. Therefore, the relations among them are complicated. So the framework can help teachers to manage the relations by information visualization. Some learners master a material course by studying it once. Other learners may not understand a material from the first time, so the situation must be different. Therefore our framework provides an examination mechanism which is shown in Fig. 8.

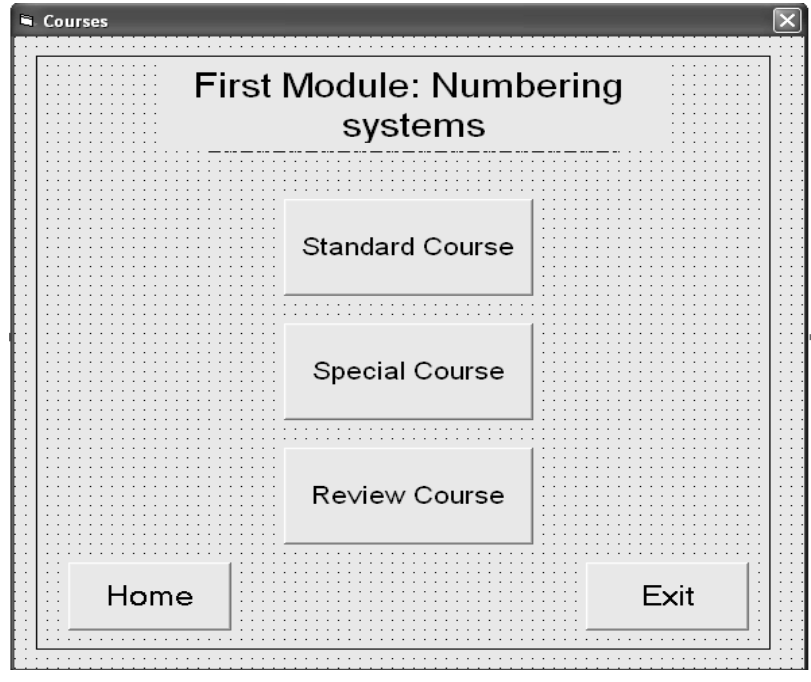

Fig. 5. Three courses for each unit

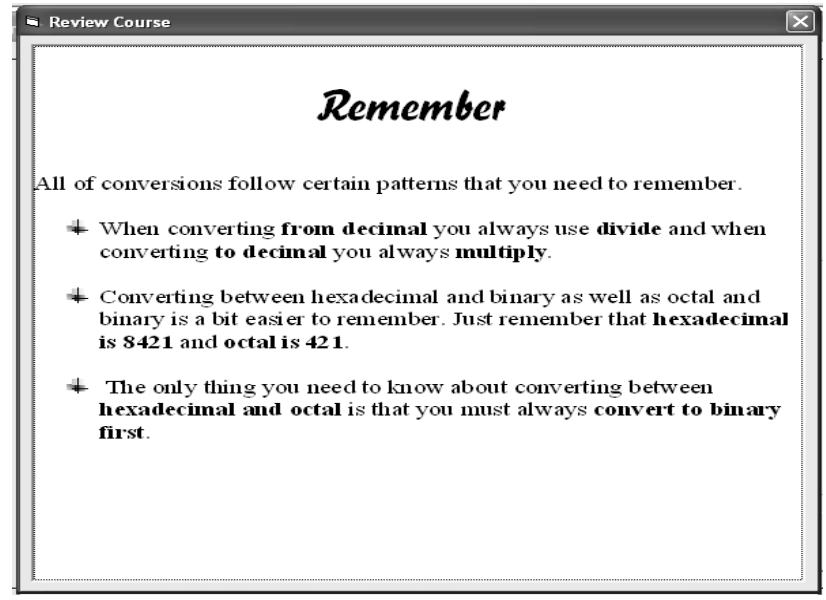

Fig. 6. Review course

Such mechanism leads to other situations according to the exam results. The framework provides examination within 10 questions as a multiple choice questions that selected randomly from database contains lots of questions and their answers. A learner may fail to passes the same examination more than one time, or may be multiple learners examined at same time and place. So, the system generates different examination pages each time. It checks the answers by comparing the learner's answer to the correct answer in the database. It displays "Wrong" as a message in case of invalid answer, and if the answer is true "Correct" message will be displayed. The displayed messages according to answers are shown in Fig. 9 and Fig. 10. After the termination of the exam, the system counts passed and failed questions. It displays the final result in a score sheet and gives a comment on results. According to the result of the examination, the system decides the next course that will be learned. 


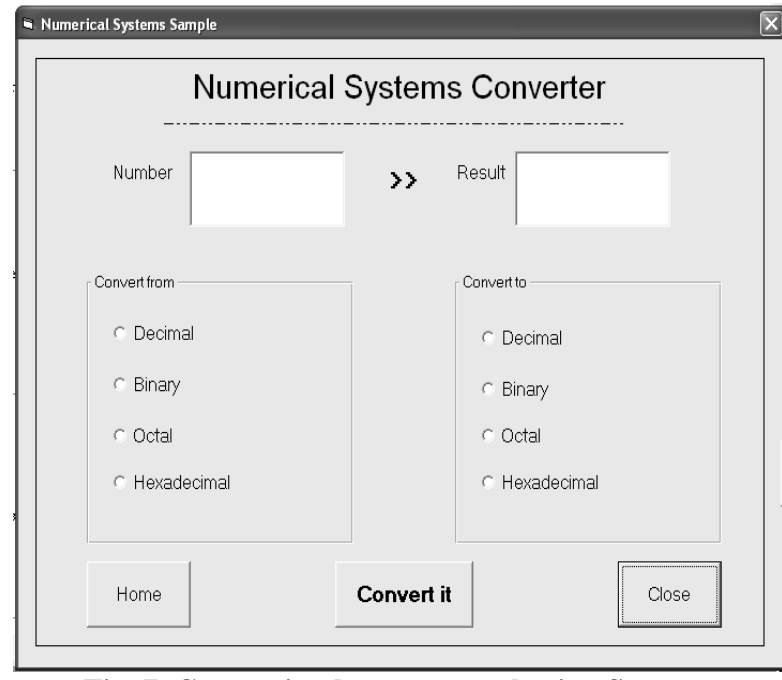

Fig. 7. Conversion between numbering Systems

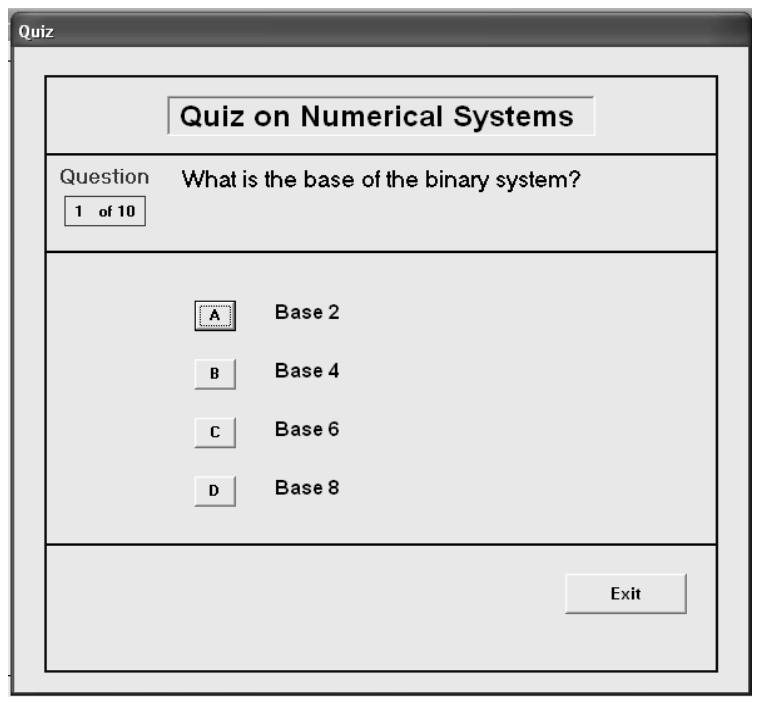

Fig. 8. Examination

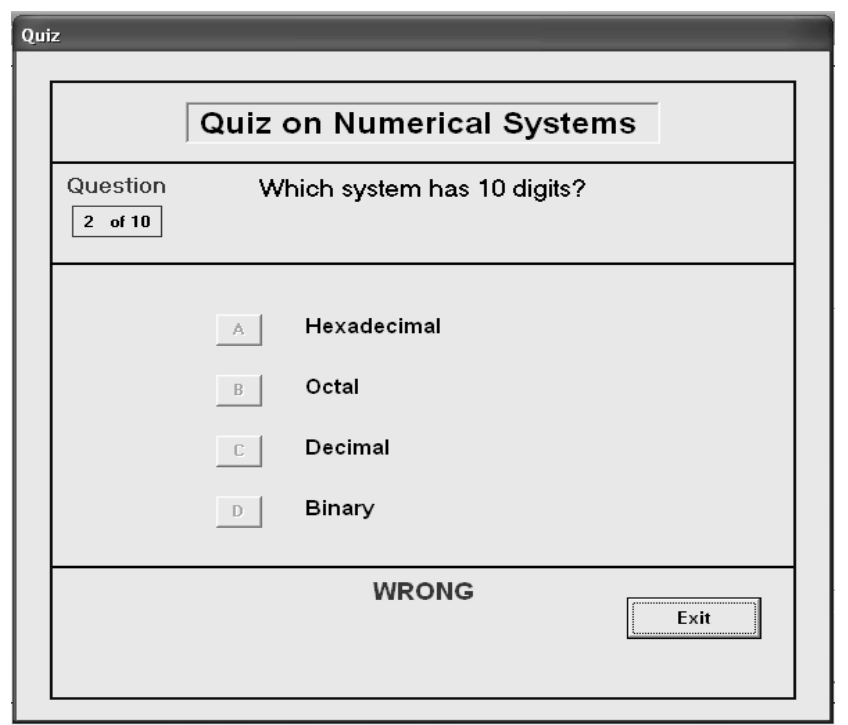

Fig. 9. Displayed message if answer is wrong

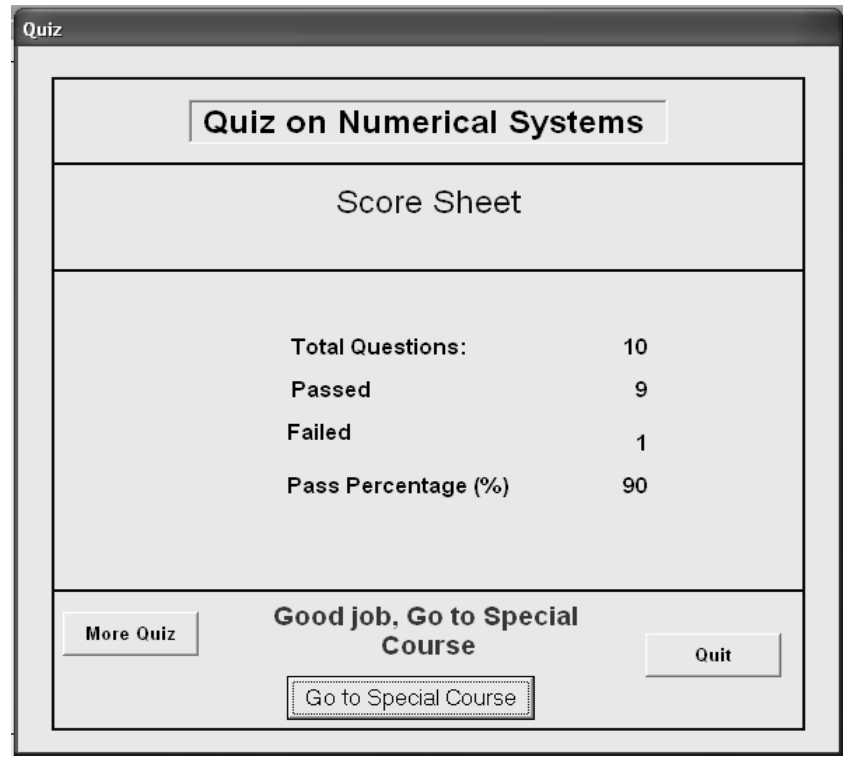

Fig. 10. Score sheet and pass percentage

The system decides the next unit according to the following four cases:

1. If a learner's pass percentage of the examination of a unit is $50 \%$ or less, then next unit is a unit which the student has tried but never passed (learner returns to the same course that never passed by him).

2. If a learner's pass percentage of the examination of a unit is $60 \%$ or $70 \%$, then next unit is the review course

3. If a learner's pass percentage of the examination of a unit is $80 \%$ or $90 \%$ because of frequently wrong answers, then the special course materials will be provided.

4. If a learner's pass percentage of the examination of a unit is $100 \%$, then the next unit will be provided.

The logic gates simulator constitutes the second component of the framework. It contains an animated welcome page (movie like) illustrated with text, pictures, animation, and speech as in Fig. 11. Our simulator defines combinational circuits, common logic gates found in digital circuits, and demonstrates course concepts. We provide links to pages where the learner can view symbols, truth tables, animation of particular logic gates. The combinational logic simulator includes encoders, decoders, multiplexer, and demultiplexer. The combinational logic gates react to the values of the signals at their inputs and produce the value of the output signal, transforming binary information from the given input data to a required output data. Fig. 12 shows the octal to binary encoder and Fig. 13 shows the multiplexer. Logic gates include AND, OR, NOT, NAND, NOR, EXOR, and EXNOR gates, in addition to Half Adder, Full Adder, and S-R FlipFlop. In Fig. 7 shows the half adder, Fig. 14 shows the EXNOR gate and Fig. 15 shows S-R Flip-Flop. 


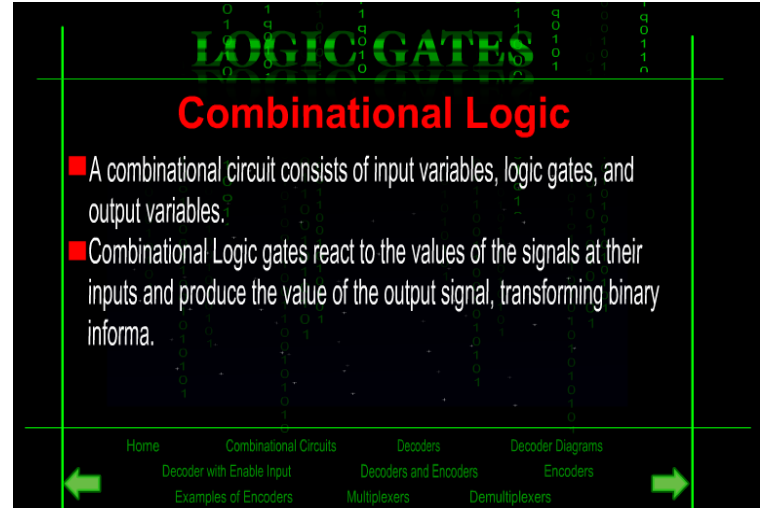

Fig. 11. Animated welcome page.

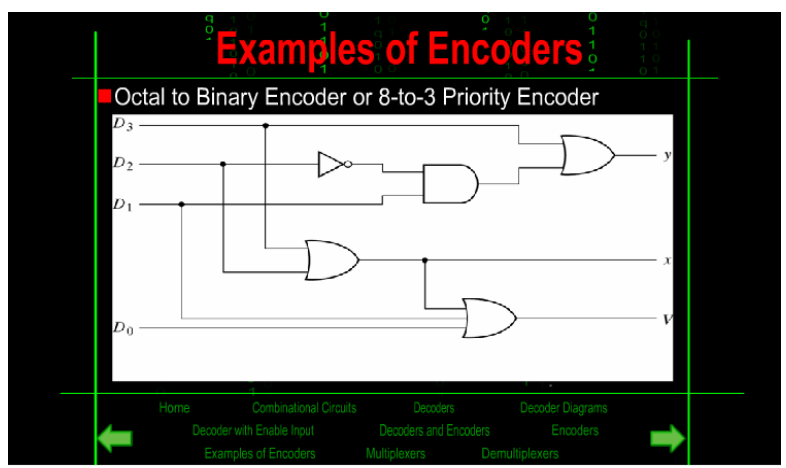

Fig. 12. Octal to binary encoder.

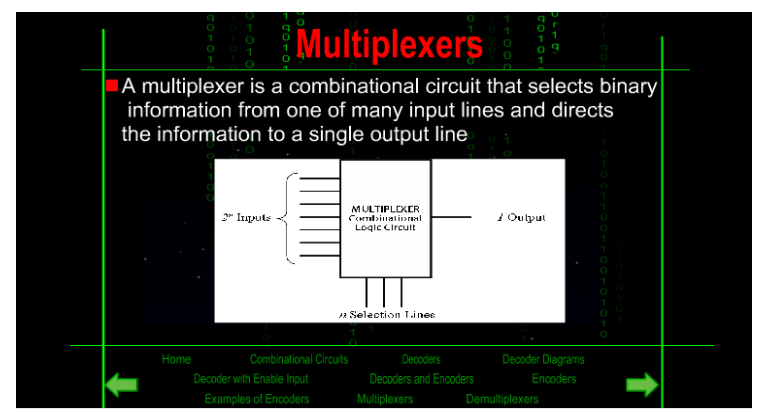

Fig. 13. Multiplexers.

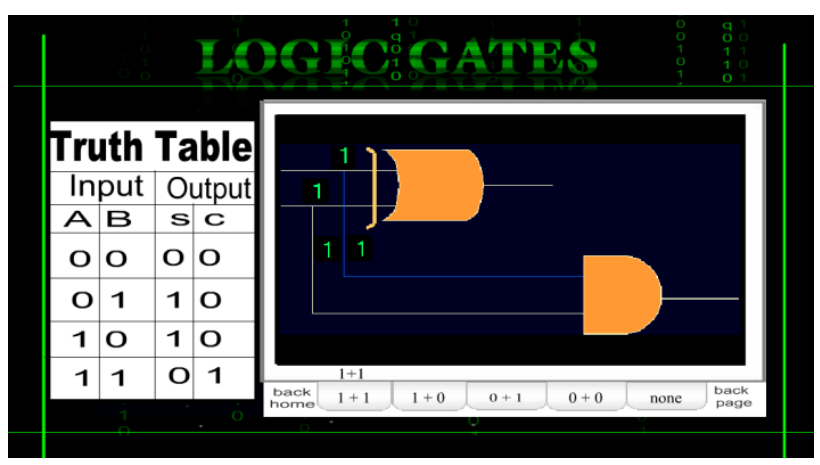

Fig. 14. Half Adder simulator.

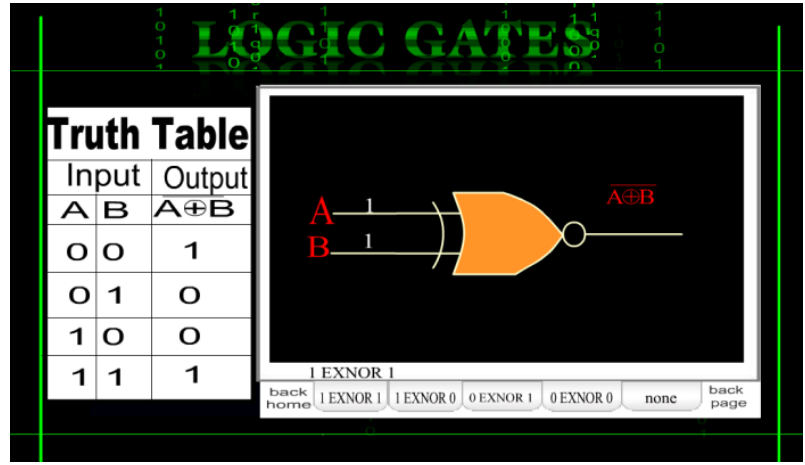

Fig. 15. EXNOR gate simulator.

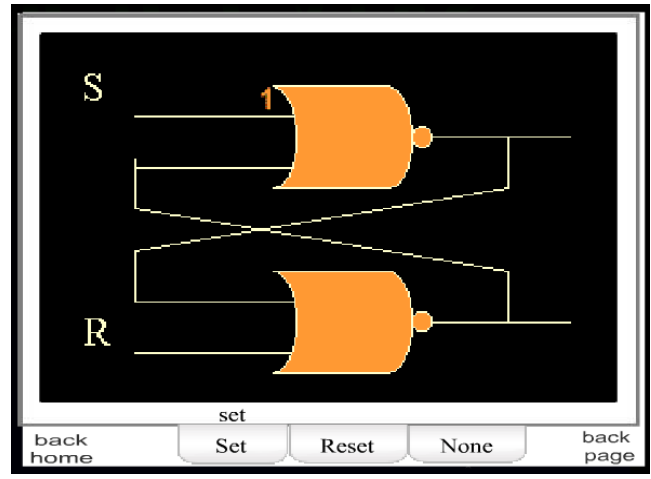

Fig. 16. S-R Flip-Flop simulator.

In the performed simulation, learners choose the input and see animated path through gate getting output in a repeated form. Learners not only watching how gates work but they can get immediate help at any step in the learning process through navigation in the introduction components. Combinational circuits' simulators are presented in Fig. 16, Fig. 17, and Fig. 18. A practical exercise is one of the environment resources. It presents visual examples that demonstrate many of the fundamental concepts of digital design; it includes simplification of Boolean functions, Complement of a Function, Minterms, Maxterms, and Karnaugh map. Fig. 19 shows a practical example. The question solved in a step-by-step manner, which can help the learner to interact with examples in an amusing way. 


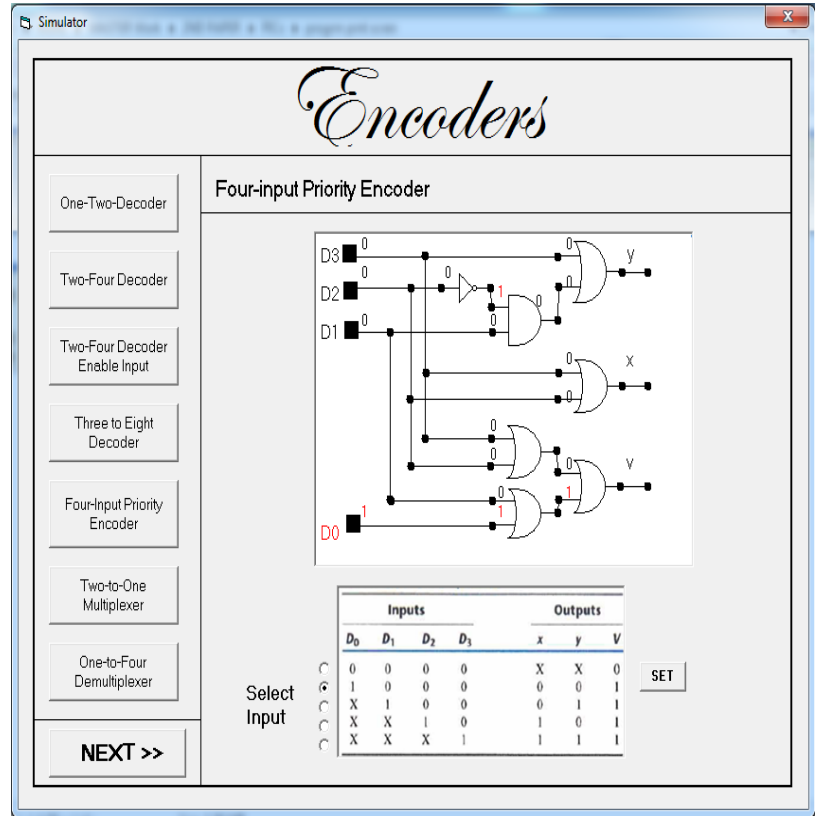

Fig.17. Encoders simulator.

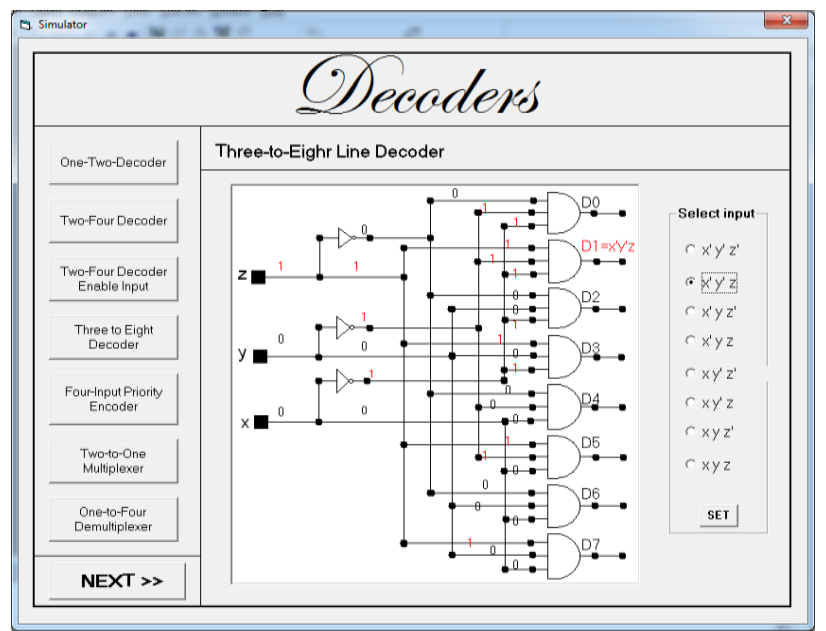

Fig. 18. Decoder simulator.

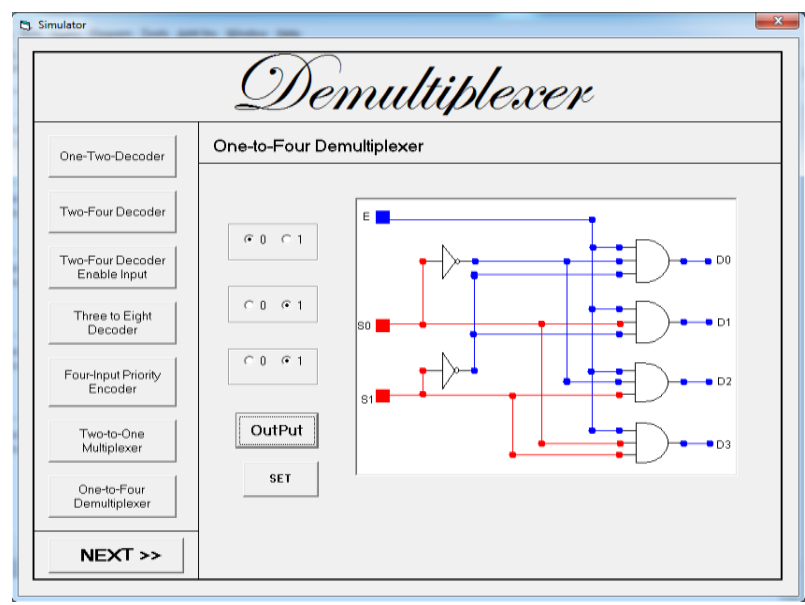

Fig. 19. Demultiplexer simulator.

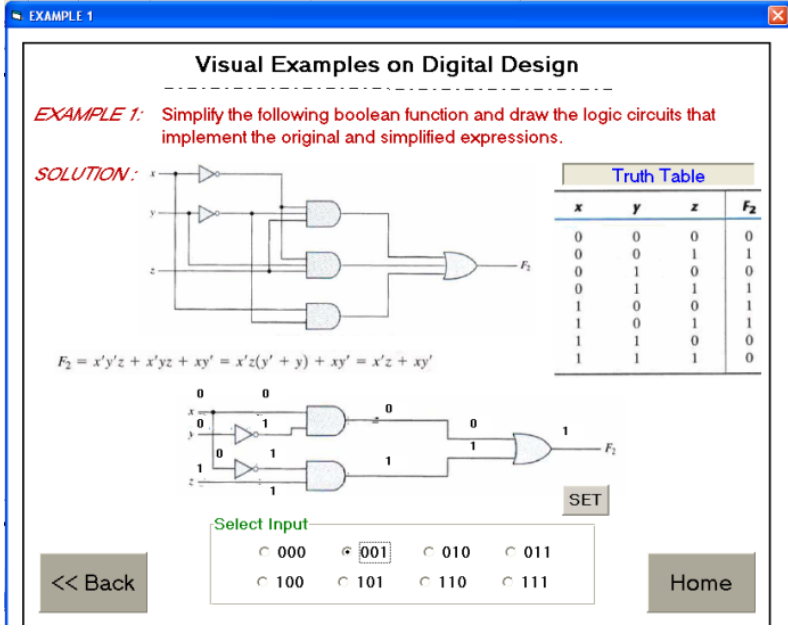

Fig. 20. Example on simplification of a Boolean function.

Some learners master a material course by studying it once. Other learners may not understand a material from the first time, so the situation must be different. Therefore our framework provides an examination mechanism. Such mechanism leads to other situations according to the exam results.

The framework provides examination within 10 questions as a multiple choice questions that selected randomly from database contains pool of questions and their answers. The questions organized by concepts. For each concept a set of standard questions was prepared capable to assess learning level of the learner. A learner may fail to passes the same examination more than one time, or may be multiple learners examined at same time and place. So, the system generates different examination pages each time. It checks the answers by comparing the learner's answer to the correct answer in the database. It displays "Wrong" as a message supported by audio in case of invalid answer, and if the answer is true "Correct" message supported by audio will be displayed. The displayed messages according to answers are shown in Fig. 21 and Fig. 22. After the termination of the exam, the system counts passed and failed questions. It displays the final result in a score sheet and gives a comment on results. According to the result of the examination, the system decides the next course that will be learned.

The system decides the next unit according to the following three cases:

1. If a learner's pass percentage of the examination of a unit is $100 \%$, then the next unit will be provided.

2. If a learner's pass percentage of the examination of a unit is $70 \%$ or $90 \%$ because of frequently wrong answers, then the special course materials will be provided. It includes course material that should be studied when learner makes popular mistakes in the examination

3. If a learner's pass percentage of the examination of a unit is $60 \%$ or less, the system presents another teaching style and so on until the score becomes acceptable. The learner profiles will be adjusted, and the next unit will be the unit that the student has tried but never passed. 
The proposed system can select suitable learning style with attention to the behavior and interest of the user as in Fig. 23. Although it pays attention to the results of exams and tests, this does not form the basis of decision making about the selected learning style.

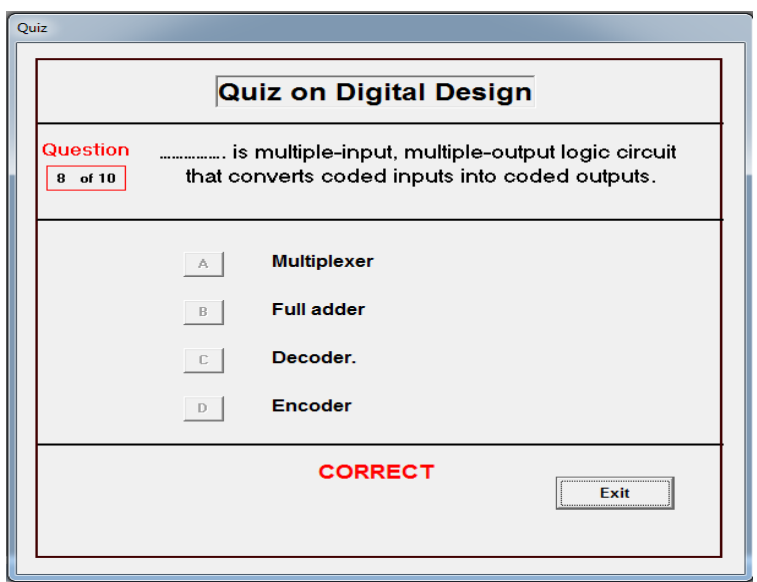

Fig. 21. Displayed message if answer is correct.

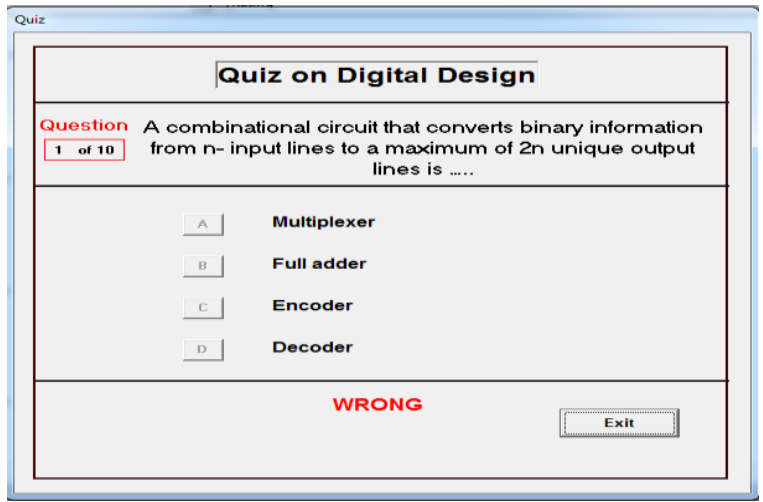

Fig. 22. Displayed message if answer is wrong.

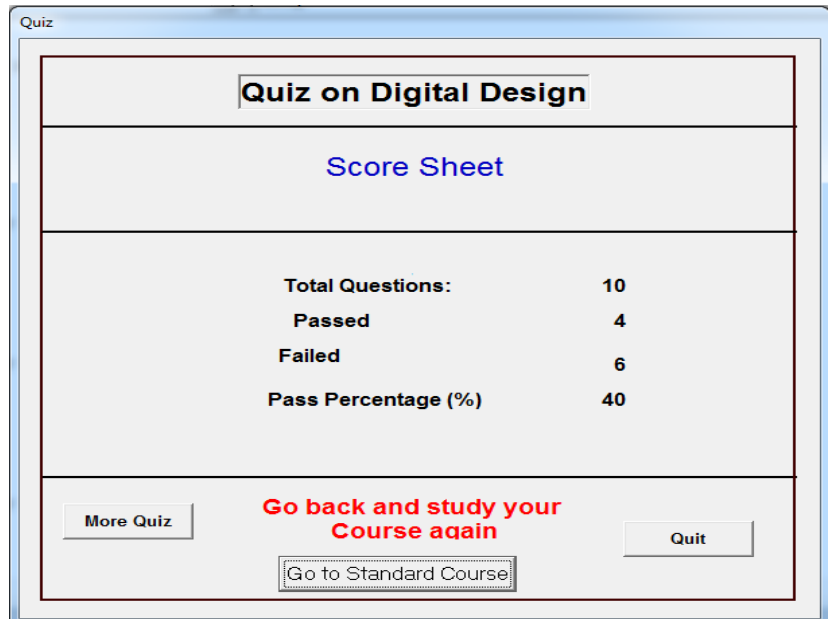

Fig. 23. Score sheet and pass percentage.

\section{EXPERIMENTAL RESULTS}

Experiments were carried out to evaluate the effectiveness of the proposed environment tools on the learning process. Forty students were randomly selected from different classrooms. They were divided into two groups. The students of first group have already completed the numeric systems course and done their exams in a traditional learning process. Then each one of the first group was given the questionnaire as shown in Table 3. The questionnaire measure four criteria named as enjoyable, fairness, flexibility, and pinpoint weakness. Five options were given for responses: (N) No answer, (1)Poor, (2)Below average, (3)Good, (4)Excellent. The responses are shown in Table 4. The proposed model and visual examples are demonstrated for the second group of students. They have been allowed to use self assessment testing system, and each of them has been given the same questionnaire. Their responses are listed in Table 5.

Table 3. Questionnaire given for students

\begin{tabular}{|c|c|c|c|c|c|}
\hline \multicolumn{6}{|c|}{ Select suitable value for each question } \\
\hline Questions & $\mathrm{N}$ & 1 & 2 & 3 & 4 \\
\hline $\begin{array}{l}\text { Do you find the learning process } \\
\text { enjoyable? }\end{array}$ & & & & & \\
\hline $\begin{array}{l}\text { Do you find the marks given to } \\
\text { you fair? }\end{array}$ & & & & & \\
\hline $\begin{array}{l}\text { Do you find the learning process } \\
\text { flexible? }\end{array}$ & & & & & \\
\hline $\begin{array}{lcc}\text { Could you identify } & \text { your } \\
\text { weaknesses in this course? } & \end{array}$ & & & & & \\
\hline $\begin{array}{r}\mathrm{N}=\text { "No answer", } 1=\text { "Poor", } 2=" \\
\text { "Good", 4= "Excel }\end{array}$ & & & & & \\
\hline
\end{tabular}

Table 4. Results of the first group

\begin{tabular}{|c|c|c|c|c|c|}
\hline \multicolumn{6}{|c|}{ Select suitable value for each question } \\
\hline Questions & $\mathrm{N}$ & 1 & 2 & 3 & 4 \\
\hline $\begin{array}{l}\text { Do you find the learning } \\
\text { process enjoyable? }\end{array}$ & 2 & 6 & 8 & 1 & 3 \\
\hline $\begin{array}{l}\text { Do you find the marks given to } \\
\text { you fair? }\end{array}$ & 1 & 3 & 7 & 8 & 1 \\
\hline $\begin{array}{l}\text { Do you find the learning } \\
\text { process flexible? }\end{array}$ & 0 & 5 & 9 & 4 & 2 \\
\hline $\begin{array}{l}\text { Could you identify your } \\
\text { weaknesses in this course? }\end{array}$ & 4 & 1 & 12 & 2 & 1 \\
\hline
\end{tabular}

$\mathrm{N}=$ "No answer", 1= "Poor", 2= "Below average", $3=$ "Good", 4= "Excellent" 
Table 5. Results of the second group

\begin{tabular}{|l|c|c|c|c|c|}
\hline \multicolumn{6}{|c|}{ Select suitable value for each question } \\
\hline \multicolumn{1}{|c|}{ Questions } & N & 1 & 2 & 3 & 4 \\
\hline $\begin{array}{l}\text { Do you find the learning process } \\
\text { enjoyable? }\end{array}$ & 0 & 1 & 0 & 11 & 8 \\
\hline $\begin{array}{l}\text { Do you find the marks given to } \\
\text { you fair? }\end{array}$ & 0 & 1 & 1 & 12 & 6 \\
\hline $\begin{array}{l}\text { Do you find the learning process } \\
\text { flexible? }\end{array}$ & 2 & 0 & 1 & 13 & 4 \\
\hline $\begin{array}{l}\text { Could you identify your } \\
\text { weaknesses in this course? }\end{array}$ & 0 & 1 & 2 & 7 & 10 \\
\hline N= "No answer", 1= "Poor", 2= "Below average", 3= \\
"Good", 4= "Excellent"
\end{tabular}

The questionnaire indicates that $95 \%$ of the students found the experience enjoyable, one student did not like the experience at all, and $90 \%$ of the respondents agreed the marks awarded by the system were fair. The result also shows that $85 \%$ of the respondents thought of flexibility of the system. Finally $85 \%$ of respondents think the system could help them pinpoint their weaknesses in numeric systems course. The results of the first group are compared without using our proposed model, and the other group used our proposed model. For Choices N, 1, and 2, if the number of response decreased, it indicates a positive response, which is what occurred. While for choices 3 , and 4 , the increasing numbers of responses indicates positive response, which also occurred.

Experiments are carried out in order to evaluate the effectiveness of our proposed tools on the learning process. Thirty students were randomly selected from different classrooms. They were divided into two groups, each one contains 15 students. The students of first group have already completed the logical design course and done their exams in a traditional learning process. Then each one of the first group was given the questionnaire in Table 6 .

The questionnaire measure five criteria named as increased motivation, flexibility, fairness, enjoyable, and pinpoint weakness. Five options were given for responses: (N) No answer, (1) Poor, (2) Below average, (3) Good, (4) Excellent. The responses are shown in Table 7.

The proposed model and visual examples are demonstrated for the second group of students. They have been allowed to use self assessment testing system, and each of them has been given the same questionnaire. Their responses are listed in Table 8.
Table 6. Questionnaire given for students.

\begin{tabular}{|c|c|c|c|c|c|}
\hline \multicolumn{6}{|c|}{ Select suitable value for each question } \\
\hline Questions & $\mathrm{N}$ & 1 & 2 & 3 & 4 \\
\hline $\begin{array}{l}\text { Do you find the learning process } \\
\text { increases your motivation in } \\
\text { learning logic design? }\end{array}$ & & & & & \\
\hline $\begin{array}{l}\text { Do you find the learning process } \\
\text { flexible? }\end{array}$ & & & & & \\
\hline $\begin{array}{l}\text { Do you find the marks given to } \\
\text { you fair? }\end{array}$ & & & & & \\
\hline $\begin{array}{l}\text { Do you find the learning process } \\
\text { enjoyable? }\end{array}$ & & & & & \\
\hline $\begin{array}{l}\text { Could you identify your } \\
\text { weaknesses in this course? }\end{array}$ & & & & & \\
\hline $\begin{array}{r}\mathrm{N}=\text { "No answer", 1= "Poor", } 2=\text { " } \\
\text { "Good", 4= "Excell }\end{array}$ & & & & & \\
\hline
\end{tabular}

Table 7. Results of the first group

\begin{tabular}{|l|l|l|l|l|l|}
\hline \multicolumn{5}{|c|}{ Select suitable value for each question } \\
\hline \multicolumn{1}{|c|}{ Questions } & $N$ & 1 & 2 & 3 & 4 \\
\hline $\begin{array}{l}\text { Do you find the learning process } \\
\text { increases your motivation in } \\
\text { learning logic design? }\end{array}$ & 0 & 4 & 4 & 5 & 2 \\
\hline $\begin{array}{l}\text { Do you find the learning process } \\
\text { flexible? }\end{array}$ & 1 & 4 & 5 & 3 & 2 \\
\hline $\begin{array}{l}\text { Do you find the marks given to } \\
\text { you fair? }\end{array}$ & 0 & 2 & 7 & 3 & 3 \\
\hline $\begin{array}{l}\text { Do you find the learning process } \\
\text { enjoyable? }\end{array}$ & 2 & 6 & 2 & 4 & 1 \\
\hline $\begin{array}{l}\text { Could you identify your } \\
\text { weaknesses in this course? }\end{array}$ & 0 & 4 & 5 & 5 & 1 \\
\hline $\begin{array}{l}\text { N= "No answer", 1= "Poor", 2= "Below average", 3= } \\
\text { "Good", 4= "Excellent" }\end{array}$ & & & & \\
\hline
\end{tabular}

The questionnaire indicates that $80 \%$ of respondents conclude that the system helps increase their motivation level in learning logic design. The result also shows that $86.6 \%$ of the respondents thought of flexibility of the system. Furthermore, $93.3 \%$ of the respondents agreed the marks awarded by the system were fair. In addition, $86.6 \%$ of the 
students found the experience enjoyable, two student did not like the experience at all, and. Finally, $80 \%$ of respondents think the system could help them pinpoint their weaknesses in logic design course, while one student doesn't answer. We compare results of the first group without using our model, and the other group used our model. For Choices N, 1, and 2, if the number of response decreased, it indicates a positive response, which is what occurred. While for choices 3 , and 4 , the increasing numbers of responses indicates positive response, which also occurred as in Fig. 15.

After the students of the second group answer the test in the Starting registration form, we make a survey to count the results of the modified learning styles test. They had to answer this test to obtain their learning styles in order to get a chance to explore the system. The results were shown in TABLE 9. The system treats different students' styles with different ways. The most important differences appear in the visual and verbal dimensions. The system shows pictures or tables for a visual style's student. While for the verbal style student shows plain text. For the other dimensions as the active or reflective, it shows very similar materials since they were answered exercises. For the sensitive or intuitive dimensions, the materials were examples with a few explanations about them. We found that the active students were more than reflective. Comparing the sensitive and intuitive dimensions the majority of the students were sensitive. The greatest gap was found between the visual and verbal dimensions. Where 12 students were visual and the rest were verbal. The 12 Advanced students prefer the educational tools while 3 Traditional students not prefer. Also the majority of students preferred standalone and only 4 students like working in groups. Finally, for the sequential and global dimensions, the preponderance was sequential.

\section{Table 8. Results of the second group}

\begin{tabular}{|c|c|c|c|c|c|}
\hline \multicolumn{6}{|c|}{ Select suitable value for each question } \\
\hline Questions & $\mathrm{N}$ & 1 & 2 & 3 & 4 \\
\hline $\begin{array}{l}\text { Do you find the learning process } \\
\text { increases your motivation in learning } \\
\text { logic design? }\end{array}$ & 0 & 1 & 2 & 6 & 6 \\
\hline $\begin{array}{l}\text { Do you find the learning process } \\
\text { flexible? }\end{array}$ & 0 & 1 & 1 & 5 & 8 \\
\hline $\begin{array}{l}\text { Do you find the marks given to you } \\
\text { fair? }\end{array}$ & 0 & 0 & 1 & 6 & 8 \\
\hline $\begin{array}{l}\text { Do you find the learning process } \\
\text { enjoyable? }\end{array}$ & 1 & 0 & 1 & 9 & 4 \\
\hline $\begin{array}{l}\text { Could you identify your weaknesses in } \\
\text { this course? }\end{array}$ & 1 & 0 & 2 & 7 & 5 \\
\hline $\begin{array}{r}\mathrm{N}=\text { "No answer", 1= "Poor", } 2=\text { "Belov } \\
4=\text { "Excellent" }\end{array}$ & & & & & \\
\hline
\end{tabular}

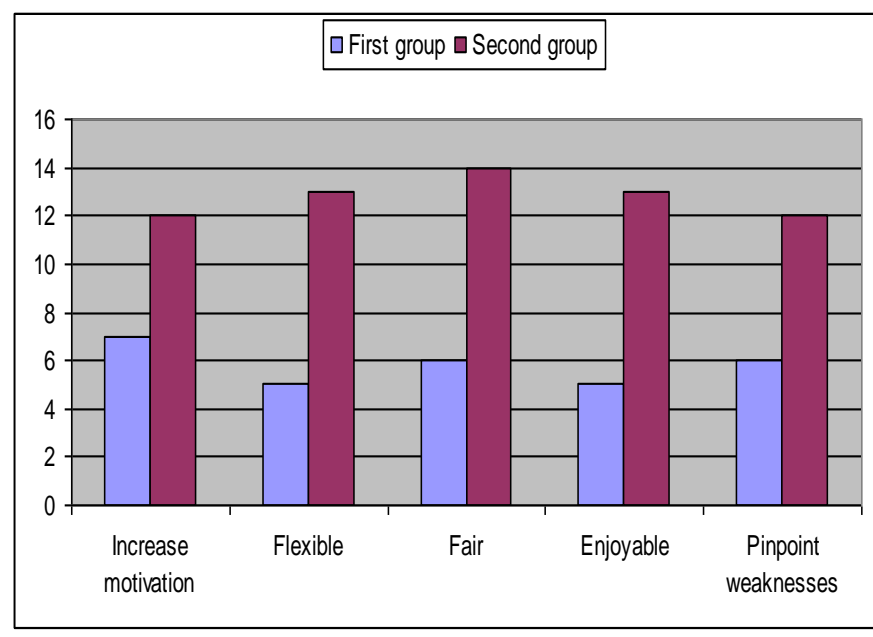

Fig. 24. Comparison between the results of the two groups

Table 9. Results of the modified learning styles test

\begin{tabular}{|c|c|c|}
\hline $\begin{array}{c}\text { Learning Style } \\
\text { Dimension }\end{array}$ & STYLE & $\begin{array}{c}\text { Number of } \\
\text { Students }\end{array}$ \\
\hline Processing & Active & 9 \\
\cline { 2 - 3 } & Reflective & 6 \\
\hline \multirow{2}{*}{ Perception } & Sensitive & 9 \\
\cline { 2 - 3 } & Intuitive & 6 \\
\hline Entry Channel & Visual & 12 \\
\cline { 2 - 3 } & Verbal & 3 \\
\hline Understanding & Sequential & 10 \\
\cline { 2 - 3 } & Global & 5 \\
\hline Realistic & Traditional & 3 \\
\cline { 2 - 3 } & Advanced & 12 \\
\hline \multirow{2}{*}{ Behavior } & Work in group & 4 \\
\cline { 2 - 3 } & Standalone & 11 \\
\hline
\end{tabular}

\section{CONCLUSIONS}

A new model for effective use of profiling, explicit feedback and learning styles in an AME-Learning environment has been presented. Such model consists of five main parts, Starting registration form, self learning materials, visualization in an interesting way, practical examples, and self testing. The framework is simple and easy to be implemented using simple tools to support adaptive ELearning systems for digital logic educational material, and it could be also used in other courses such as image processing, computational models, information theory, information engineering and digital communications. The framework finds a better way to engaging learners in the learning process. To deeply recognize the learner's styles, new items have been added to both the dimensions of Felder-Silverman learning style model and our previous work. Moreover, it identifies user's strengths and weaknesses and then adapting user's study sessions to his personal needs. Through the results of our experiment, it has been shown that our proposed model improves the learning process, and affects the students in a positive way. In addition an opinion poll showed a positive feedback on the environment tools from the students. In future work, we plan to enhance our tools by adding more features, visual examples, and make more performance evaluation experiments. 


\section{REFERENCES}

[1] A. M. Riad, Hazem M. El-Bakry, and Samir M. Abd Elrazek, "Design and Evaluation of Medical E-Learning Model," the $3^{\text {rd }}$ WSEAS International Conference on Bioscience and Bioinformatics (ICBB '12), Montreux, Switzerland, December 29-31, 2012, pp. 265-272.

[2] N. S. Abu El-Ala, W. A. Awad and H. M. El-Bakry, “ Cloud Computing for Solving E-Learning Problems," International Journal of Advanced Computer Science and Applications, vol. 3, No. 12, December 2012,pp. 135137.

[3] Hazem El-Bakry, and Mohamed Hamada, "Adaptive ELearning for Data Encoding and Computer Networks based on Learner's Styles," International Journal of Computer Networks and Security, vol. 22, issue 12, December 2012, pp. 333-142.

[4] A. M. Riad, Hazem M. El-Bakry, and Samir M. Abd Elrazek, "Construction and Evaluation of Medical ELearning System," International Journal of Computational Linguistics and Natural Language Processing, vol. 1, issue 4, November 2012, pp. 98-106.

[5] A. M. Riad, Hazem M. El-Bakry, and Samir M. Abd Elrazek, "Simulation of Medical Consultation on Virtual Patient," International Journal of Computational Linguistics and Natural Language Processing, vol. 1, issue 3, October 2012, pp. 60-64.

[6] A. M. Riad, Hazem M. El-Bakry, and Samir M. Abd Elrazek, "Design of Virtual Environment for Medical ELearning," Global Advanced Research Journal of Engineering, Technology and Innovation, vol. 1, no. 6, September 2012, pp. 138-147.

[7] A. M. Riad, Hazem M. El-Bakry, and Samir M. Abd Elrazek, "Virtual Investigation of Patients for Medical ELearning," International Journal of Computer Science and Information Security, vol. 10, no.7,August, 2012, pp.6-10.

[8] Hazem M. El-Bakry, Ahmed A. Saleh and, Taghreed T. Asfour, "A Novel Adaptive E-Learning Model Based on Developed Learner's Styles," World Academy of Science, Engineering and Technology, vol. 60, 2011,pp.1946-1953

[9] Hazem M. El-Bakry, Ahmed A. Saleh, Taghreed T. Asfour, and Nikos Mastorakis, "A New Adaptive ELearning Model Based on Learner's Styles," Proc. of $13^{\text {th }}$ WSEAS Int. Conf. on MATHEMATICAL and COMPUTATIONAL METHODS in SCIENCE and ENGINEERING (MACMESE '11), Catania, Sicily, Italy, November 3-5, 2011, pp. 440-448.

[10] A. M. Riad, H. K. Elminir, H. M. El-bakry and H. A. ElGhareeb, " Supporting Online Lectures with Adaptive and intelligent Features", International Journal of Research and Innovation, Advances in Information Sciences and Service Sciences (AISS), Vol.3 , No.1, 2011, pp. 47-53.

[11] Alaa M. Riad, Hazem M. El-Bakry, Hamdy K. Elminir, and Haitham A. El-Ghareeb, "Adaptive and intelligent ELearning Model as a Solution for current E-learning Challenges," Mansoura Journal for Computer Science and Information Systems, vol. 1, no. 8, Jan 2010, pp. 1525.
[12] Ahmed A. Saleh, Hazem M. El-Bakry, and Taghreed T. Asfour, "Design of Adaptive E-Learning for Logic Operations," International Journal of Education and Information Technologies, issue 2, vol. 4, 2010, pp. 4956

[13] Ahmed A. Saleh, Hazem M. El-Bakry, Taghreed T. Asfour, and Nikos Mastorakis "Adaptive E-Learning Framework for Digital Design," Proc. of $9^{\text {th }}$ WSEAS International Conference on Telecommunications and Informatics, Italy, May 29-31, 2010, pp. 176-182.

[14] Ahmed A. Saleh, Hazem M. El-bakry, Taghreed T. Asfour, and Nikos Mastorakis "Adaptive E-Learning Tools for Numbering Systems," Proc. of 9th WSEAS International Conference on Applications of Computer Engineering (ACE'10), Penang, Malaysia, March 23-25, 2010, pp. 293-298.

[15] Ahmed A. Saleh, Hazem M. El-Bakry and, Taghreed T. Asfour, "AN ADAPTIVE E-LEARNING MODEL BASED ON LEARNER'S STYLES," Mansoura Journal for Computer Science and Information Systems, vol. 1, no. 8 , Jan 2010 , pp. 67-70.

[16] Ahmed A. Saleh, Hazem M. El-Bakry, and Mahmud Atta Alla, " Designing E-learning Management System Frame work For Telecom Egypt Training Sector," Mansoura Journal for Computer Science and Information Systems, vol. 1 , no. 8, Jan 2010, pp. 51-60.

[17] Hazem M. El-Bakry, and Nikos Mastorakis, "Realization of E-University for Distance Learning," WSEAS Transactions on Computers, issue 1, vol. 8, Jan. 2009, pp. $48-62$.

[18] Hazem M. El-Bakry, and Nikos Mastorakis "Advanced Technology for E-Learning Development," Proc. of Recent Advances in Applied Mathematics and Computational and Information Sciences, Houston, USA April 30-May 2, 2009, pp. 501-522.

[19] Charles D. Dziuban, Joel L. Hartman, Patsy D. Moskal, "Blended Learning", Vol. 2004, Issue 7, Educase Connect, 2004.

[20] D. Randy Garrison, and Heather Kanuka,"Blended learning: Uncovering its transformative potential in higher education", The Internet and Higher Education, Volume 7, Issue 2, 2nd Quarter 2004, pp. 95-105.

[21] M. Hamada, "Supporting Materials for Active e-Learning in Computational Models," $8^{\text {th }}$ international conference on Computational Science, Part II, Springer-Verlag Berlin, Heidelbergm, 2008, pp. $678-686$.

[22] M. Hamada, "Visual Tools and Examples to Support Active E-Learning and Motivation with Performance Evaluation," Lecture Notes in Computer Science, vol. 3942, Springer-Verlag Berlin, Heidelberg, 2006, pp. 147 155.

[23] M. Hamada. "Web-based Tools for Active Learning in Information Theory," Proceedings of the $38^{\text {th }}$ SIGCSE technical symposium on Computer science education vol. 38, 2007, pp. 60-64.

[24] M. Hamada, An Example of Virtual Environment and Web-based Application in Learning, International Journal of Virtual Reality, Vol. 7 No. 3, 2008, pp. 1-9. 
[25] Y. Tamura, T. Yamamuro, and T. Okamoto, "Distributed and Learner Adaptive E-Learning Environment with Use of Web Services," Proceedings of the Sixth International Conference on Advanced Learning Technologies, 2006.

[26] P. Kanaksabee, M. P. Odit, A. Ramdoyal " A StandardBased Model For Adaptive E-Learning Platform For Mauritian Academic Institutions," Journal of International Education Research , Vol 7 No. 1, 2011, p.p.109-118.

[27] T.I. Wang, K.T.Wang and Y.M. Huang: Using a stylebased ant colony system for adaptive learning. ESWA, 2449-2464 (2008)

[28] Yasir Eltigani Ali Mustafa and Sami Mohamed Sharif, "An approach to Adaptive E-Learning Hypermedia System based on Learning Styles (AEHS-LS): Implementation and evaluation," International Journal of Library and Information Science, Vol. 3 No. 1, 2011, pp. $15-28$.

[29] Paramythis and Reisinger. "Adaptive Learning Environments and E-Learning Standards". Electronic Journal of eLearning 2004. http://www.ejel.org/volume2/vol2-issue1/issue1-art11-paramythis.pdf. Retrieved 2010-03-13.

[30] Practical Mobile eLearning Today: Real Solutions for Creating mLearning for Your Organization Right Now, Part

http://blogs.adobe.com/captivate/2012/04/practicalmobile-elearning-today-real-solutions-for-creatingmlearning-for-your-organization-right-now-part-1.htm

[31] Fröschl, 2005 Fröschl, C. (2005). "User modeling and user profiling in adaptive E-Learning systems: an approach for a service-based personalization solution for the research project ADELE (Adaptive E-Learning with eye-tracking)", unpublished master's thesis, Institute for Information Systems and Computer Media (IICM), Faculty of Computer Science, Graz University of Technology, Graz, Austria.

[32] Robal, T. Kalja, A., "Applying e-Environments in Teaching the Basics of Digital Logic," mse, pp.41-42, 2007 IEEE International Conference on Microelectronic Systems Education (MSE'07), 2007.

[33] Al-Zoubi, Abdullah and Jeschke, Sabina and Natho, Nicole and Pfeiffer, Olivier and Nsour, Jarir (2008) Integration of an Online Digital Logic Design Lab for IT Education. In: Proceedings of the 2008 ACM Information Technology Education Conference, ACM, pp. 237-241. ISBN 978-1-60558-329-7.
[34] Damm, M., Bauer, F., Zucker, G. "Solving Digital Logic Assignments with Automatic Verification in SCORM Modules", accepted at the ICL 2009.

[35] M Grigoriadou, Papanikolaou, K. Kornilakis. "INSPIRE: an intelligent system for personalized instruction in a remote environment", 3rd Workshop on Adaptive Hypertext and Hypermedia. Sonthofen, Germany, 2001

[36] K. Logan, K., P. Thomas: Learning style in Distance Education Students Learning to Program, Proc. Work. Psy. Prog. Int. group, Brunel University, pp. 29-44 (2002)

[37] E. El Bachari, E. Abdelwahed, M.El Adnani "Design of an Adaptive E-Learning Model Baased on Learner's Personality", MIC' 10 International Conference, RabatMorocco, November 2010.

[38] R. M. Felder, L. K. Silverman.: Learning and Teaching Styles in Engineering Education, EE, 78 (7), 674-681 (1988).

[39] Y.C. Liao, "Effects of hypermedia on students" achievement: A meta-analysis. Journal of Educational Multimedia and Hypermedia, 1999 pp. 255-277.

[40] L.J. Najjar, "Multimedia information and learning" Journal of Educational Multimedia and Hypermedia, 1996, pp. $129-150$

[41] A. L. Franzoni, A. L. and S. Assar: Student Learning styles Adaptation Method on Teaching strategies and Electronic Media, Edu. Tech. Soc. 12 (4) 15-29 (2009).

[42] P. Paredes and P. Rodriguez, "Considering sensingintuitive dimension to exposition-exemplification in adaptive sequencing", In Proceedings of the AH2002 Conference.Malaga, Spain, 2002, pp. 556-559.

[43] Hong, Hong, Kinshuk. "Adaptation to Student Learning Styles in Web Based Educational Systems." Proceedings of ED-MEDIA 2004 - World Conference on Educational Multimedia, Hypermedia \& Telecomunications. Lugano, Switzerland: L. Cantoni \& C. McLoughlin, 2004, pp. 21 26.

[44] A.L. Franzoni, and S. Assar.'Using Learning Styles to enhance an E-Learning System.”, Proceedings of the 6th European Conference on E-Learning (ECEL 2007). Academic conference management (ACI),Copenhagen, Denmark, 2007, pp. 235-244. 